\title{
Türkiye'de Ekolojik Ayak İzi ve Biyokapasite Arasındaki İlişki: Bootstrap Rolling Window Nedensellik Testi
}

\section{Doç. Dr. Türker Şimşek ${ }^{1}$ \\ Öğr. Gör. Mücella Bursal ${ }^{2 *}$}

Geliș tarihi: 01.09.2019

Kabul tarihi: 26.09.2019

\section{Atıf bilgisi:}

IBAD Sosyal Bilimler Dergisi

Sayı: Özel Sayı Sayfa: 452-465

Yıl: 2019

This article was checked by iThenticate Similarity Index $15 \%$.

1 Tokat Gaziosmanpaşa Üniversitesi, Türkiye, turker.simsek@gop.edu.tr ORCID ID 0000-0001-7581-7590

2 Sivas Cumhuriyet Üniversitesi, Türkiye, mubursal@,cumhurivet.edu.tr ORCID ID 0000-0003-2744-355X

\footnotetext{
* Sorumlu yazar
}

\section{öz}

Ekolojik ayak izi kavramı, insan etkisi ile çevresel bozulmanın bir göstergesi olup 1990'lardan itibaren bilimsel olarak literatürde yer almaya başlamıştır. Bu çalışmada Türkiye ve dünyanın ekolojik ayak izi ve biyolojik kapasite haritası incelenmiş ve mevcut eğilimlere göre gelecekte insanlığı hangi senaryoların beklediğine değinilmiştir. Türkiye'de biyokapasite ve ekolojik ayak izi arasındaki etkileşimi araştırmak için ise 1961-2016 yılları arasındaki veriler nedensellik analiz yöntemi ile incelenmiştir. Analiz sonuçlarına göre ilgili yıllarda hem ekolojik kapasiteden biyokapasiteye hem de biyokapasiteden ekolojik kapasiteye nedensellik bulgusuna rastlanmış, bu iki değişkenin uzun dönemde birlikte hareket ettiği sonucuna ulaşılmıştır.

Anahtar Kelimeler: Biyokapasite, Ekolojik Ayak İzi, Ekosistem, Nedensellik Analizi 
The Relationship between the Ecological Footprint and Biocapacity in Turkey: Bootstrap Rolling Window Causality Test

\author{
Assoc. Prof. Dr. Türker Şimşek \\ Lec. Mücella Bursal ${ }^{2 *}$
}

First received: 01.09.2019

Accepted: 26.09.2019

\section{Citation:}

IBAD Journal of Social Sciences

Issue: Special Issue Pages: 452-465

Year: 2019

This article was checked by iThenticate. Similarity Index $15 \%$.

1 Tokat Gaziosmanpaşa University, Türkiye, turker.simsek@gop.edu.tr ORCID ID 0000-0001-7581-7590

2 Sivas Cumhuriyet University, Türkiye, mubursal@,cumhuriyet.edu.tr

ORCID ID 0000-0003-2744-355X

* Corresponding Author

\begin{abstract}
Ecological footprint, which is an indicator of human impact and environmental degradation, has been used in the scientific literature since the 1990s. This study examined the ecological footprint and biocapacity map of Turkey and the world in order to explain the future scenario that will face the humanity as the current trend continues. In order to investigate the interaction between biocapacity and ecological footprint in Turkey, the related data between the years of 1961-2016 were examined by causality analysis. According to the results of the analysis, both causal findings from ecological capacity to biocapacity and from biocapacity to ecological capacity were found in the related years and it was concluded that these two variables act together in the long term.
\end{abstract}

Keywords: Biocapacity, Ecological Footprint, Ecosystem, Causality Analysis 


\section{GİRIŞ}

Ekonomik faaliyetlerin nihai amacı insanların ihtiyaç ve isteklerini karşılayarak toplumun refah seviyesinin yükseltilmesidir. Bu sebeple ekonomi ile uğraşanlar üretimi ve geliri artırarak toplumun refahını en üst seviyeye çıkarmak isterler. Ekolojik sistemin yüzyıllardır insan refahını güçlendirmesine rağmen, tarım, sanayi, balıkçılık ve uluslararası ticaret gibi insan faaliyetleri ekolojik sistem üzerinde gittikçe artan bir baskı oluşturmaktadır. Gelirlerini artırmaya yönelik çalışmalar yapan bazı ülkeler çevresel tahribat, iklim değişikliği ve küresel 1sınma gibi sorunları göz ardı edebilmektedirler. Sadece üretim ve gelir artışına dayalı politika tercih eden ülkelerde çevre sorunları çok fazla dikkate alınmadığı için kalkınmanın sürdürülebilirliği sorgulanır hale gelmektedir (Aydın vd., 2018, s.558). Günümüzde çevrenin ekonomik ve kıt mal olarak kabul edilmeye başlamasıyla birlikte, küresel 1sınma, iklim değişikliği, çevre kirliliği gibi sorunlar aslında çevrenin önemini odak noktası haline getirmiştir. $\mathrm{Bu}$ yüzden birçok bilim insanı çevre sorunları ile ilgili çalışma konusu bulmuştur. Hatta bu sorunlar disiplinler arası çalışma alanını oluşturmaktadır. Gerek makro iktisat, gerekse mikro iktisat disiplini, hatta siyasetçiler ve politika yapıcılar bu alana doğru bir yöneliş içerisine girmişlerdir (Başoğlu ve Akyazı, 2015, s.130). Bu nedenle, çevre ekonomistlerinin ve politika yapıcıların dikkati, iklim değişikliği sorununu ve bununla ilgili artan tehditleri ele almak için bir noktada toplanmıştır. İklim değişikliğine duyulan büyük ilgi, ekonomik büyümeden ziyade ekolojik olarak uygun ekonomik büyüme ile ilgili paradigmaları değiştirerek, ekonomistlerin ve politika yapıcıların çevre üzerindeki olası etkilerine bakış açısını değiştirmiştir (Alam vd., 2016, s.466).

Çevre sorunlarının giderek artması ve birçok sorunu beraberinde getirmesi nedeniyle eko-kent, ekolojik enerji, yeşil sertifika, eko-etiket gibi yeni kavramlar literatürde yer almaya başlamıştır. Bu kavramlardan birisi de ekolojik ayak izi kavramıdır. Ekolojik ayak izi, çevre üzerinde insan faaliyetlerinin baskısını yansıtır ve insanlar tarafindan kullanılan çevresel bozulmanın bir göstergesidir (Ulucak ve Bilgili, 2018, s.1). Sürdürülebilir bir çevreyi ölçülebilir yapan bu kavram, insan ve çevre arasındaki etkileşimi incelerken, doğal kaynak kullanımı üzerindeki baskının sebep ve sonuçları üzerinde yoğunlaşır. Konuyla ilgili diğer bir güncel kavram ise biyolojik kapasite kavramıdır. Biyolojik kapasite herhangi bir coğrafi bölgenin yenilenebilir doğal kaynakları üretme kapasitesini göstermektedir. Bir yerin biyolojik kapasitesini o yerin tarımsal arazileri, otlakları, balıkçılık sahaları, orman arazilerinin yüz ölçümü, toprağın ve suyun hangi miktarda üretken olması belirlemektedir. Biyolojik kapasite, alan cinsinden küresel hektar (kha) ile hesaplanır (WWF, 2012, s.6).

$\mathrm{Bu}$ çalışmada sürdürülebilir bir dünya ve kalkınma için hem Türkiye, hem de dünyanın ekolojik ve biyolojik kapasite haritası incelenmiş mevcut durumda ve gelecekte insanlığ hangi senaryoların beklediğine değinilmiştir. Çalışmada giriş, ekolojik ayak izi ve biyolojik kapasite kavramlarının Türkiye ve küresel ölçekteki durumu, konu ile ilgili yapılan literatür araştırması ve daha sonrasında Türkiye'de ekolojik ayak izi ve biyolojik kapasite arasındaki ilişkinin nedensellik analizi yapılarak sonuç ve öneriler geliştirilmiştir.

\section{EKOLOJIK AYAK IZI VE BIYYOLJIK KAPASITE KAVRAMI, TÜRKIYYE VE KÜRESEL ÖLÇEKTE MEVCUT DURUM}

1970'lerden itibaren küresel olarak en çok sorgulanan konuların başında çevre kirliliği, iklim değişikliği ve küresel ısınma sorunları gelmektedir. Bu sebeple, çevre bilimciler 1990'ların başlarında insanlar tarafından doğal kaynakların ne oranda kullanıldığını ve doğal çevrede yapılan tahribatın miktarını ölçmeye yarayan bir kavram olarak "Ekolojik Ayak İzi" (Ecological Footprint) kavramını geliştirmişlerdir (Birkan, 2014, s.1). Dünya Doğayı Koruma Vakfı (WWF) tanımlamalarına göre ekolojik ayak izi, sahip olunan teknoloji ve kaynaklarıyla bir bireyin ya da toplumun tükettiği kaynakları üretmek ve ortaya çıkan atıkları yok etmek için gerekli, biyolojik olarak verimli toprak ve su alanları olarak tanımlanır ve en genel anlamıyla çevresel sürdürülebilirliği ölçmektedir. Ekolojik ayak izinin belirlenmesinde iki önemli gösterge olarak, tüketimin ekolojik ayak izi ve biyolojik kapasite dikkate alınır. Tüketimin ekolojik ayak izi, toplum tarafından tüketilen ürünleri üretmek için kullandığımız yenilenebilir doğal kaynakları ifade etmektedir. Biyolojik kapasite ise bir coğrafi bölgenin yenilenebilir doğal kaynakları üretme kapasitesinin göstergesidir. Kişi başına düşen tüketimin ekolojik ayak izi 
miktarının, kişi başına düşen biyolojik kapasiteyi aşması, o bölgede yaşayan insanların tüketim biçimlerinin sürdürülemeyeceği anlamına gelmektedir (WWF, 2012, s.6).

Tüketim ve üretimin ekolojik ayak izi Şekil 1'deki gibi yıllar itibariyle incelendiğinde, 1961 ile 1990 yılları arasında Türkiye'nin biyolojik kapasitesinin hem üretim hem de tüketimdeki ekolojik ayak izi değerlerinden yüksek olmasına karşın, üretim ve tüketimdeki toplam ekolojik ayak izinin biyolojik kapasiteyi aştığı görülmektedir. Bu kapasite aşımı da yıllar ilerledikçe artmaktadır. 1991 yılından itibaren ise hem üretimin, hem de tüketimin ekolojik ayak izi oranları tek başlarına dahi biyolojik kapasiteyi aşmaktadır. Bu da Türkiye'deki kaynak tüketiminin sürdürülebilir olmadığını ve biyolojik kapasiteyi artırmak için kaynağa ihtiyaç duyulduğunu göstermektedir.

Şekil 1: Türkiye’nin Biyolojik Kapasitesi ve Ekolojik Ayak İzi, 1961-2007

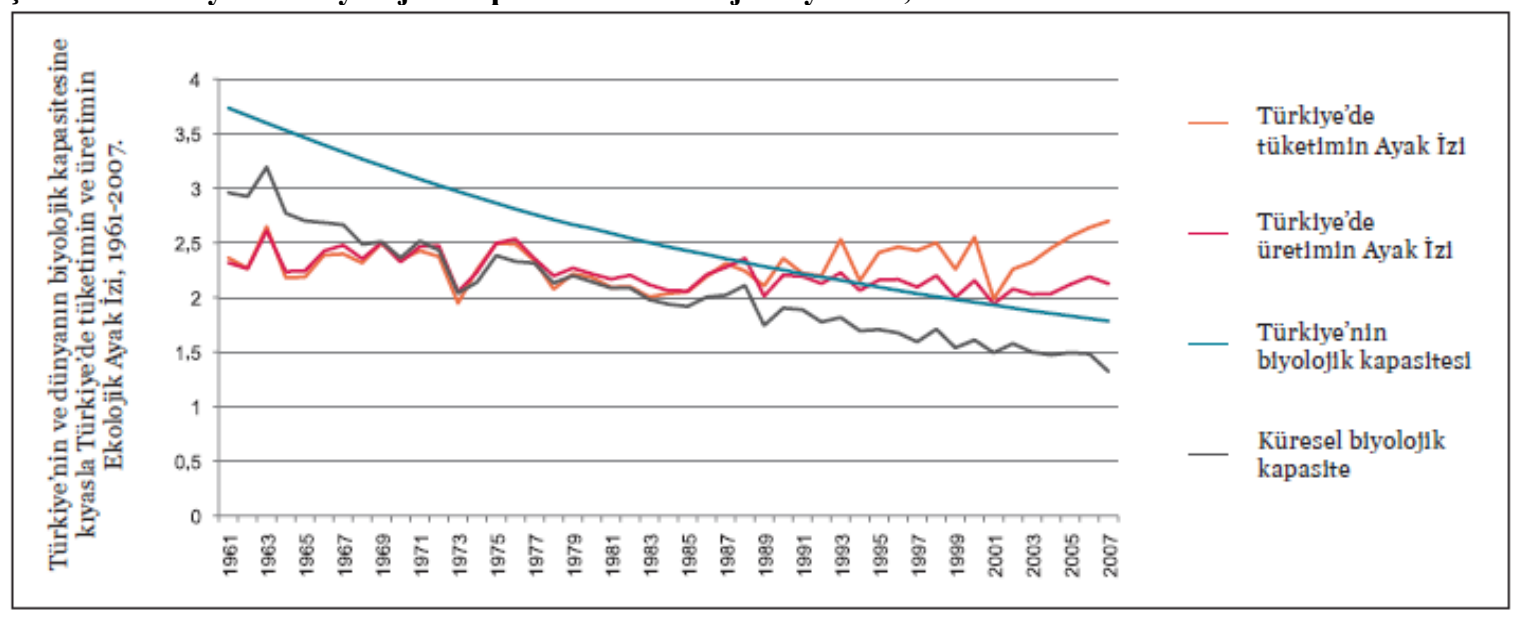

Kaynak: WWF, 2012, s.8

Türkiye'de ekolojik ayak izi ile ilgili ilk ve son kez 2012 y1lında hazırlanan WWF raporuna göre 2007 yılında Türkiye'de kişi başına düşen tüketimin ekolojik ayak izi 2.7 kha olduğu hesaplanmış olup, bu değere göre kişi başına düşen ekolojik ayak izi miktarı küresel biyolojik kapasitenin \%50 fazlasına karşı1lı gelmektedir. Bu durumun diğer bir ifadesi; dünyadaki herkesin ortalama bir Türkiye vatandaş1 kadar tüketim yaptığı durumda, doğal kaynaklarla tüketimin ekolojik ayak izini karşılamak için 1.5 dünya gezegenine ihtiyacımız olacağıdır. Türkiye özellikle son yıllarda kendini yenileyebilme hızına göre doğal kaynaklarını daha hızlı tükettiği için ekolojik açıdan dünya geneline borçlu ülkeler arasında yer almaktadır. 1990'lara kadar Türkiye, biyolojik kapasite fazlasına sahipken, günümüzde biyolojik kapasite açı̆̆ına gelmesinin en temel nedeni olarak ise son yıllardaki nüfus artışı olarak gösterilmektedir (WWF, 2012, s.7). Türkiye'de yaşanılan nüfus artış oranları, son on yılda Dünya Bankası verilerine göre ortalama olarak her yıl yüzde 1.56 civarındadır. Türkiye İstatistik Kurumu'nun adrese dayalı nüfus kayıt sistemi sonuçlarına göre Türkiye'de ikamet eden nüfus 2018 yılında, bir önceki yıla göre 1 milyon 193 bin 357 kişi artmıştır.

Şekil 2'de ise Dünya'da mevcut duruma göre biyokapasitenin tüketimin ve üretimin ayak izini karşılama oranının değişimi grafiksel olarak gösterilmiştir. 1960 ile 1980 yıllarının ortalarına kadar küresel ölçekte dünyanın biyokapasitesi, küresel üretim ve tüketimdeki ayak izlerinin sadece birini karşılamakta iken, 1990'lardan itibaren hem üretimdeki hem de tüketimdeki ayak izlerinin dünya biyokapasitesini aşmakta olduğu görülmektedir. 2050 yılına kadarki süreç için yapılan tahmini senaryoda ise, Dünya biyokapasitesi yıllar içinde korunduğu takdirde sabit kalırken, üretim ve tüketimdeki ayak izlerinin sürekli biçimde artış eğiliminde olması sürdürülebilir kalkınma açısından oldukça olumsuz bir tablo ortaya koymaktadır. 
Şekil 2: Mevcut Durumun Devamına Dayanan Senaryoda Toplam Ekolojik Ayak İzi ve Biyokapasite Değerleri

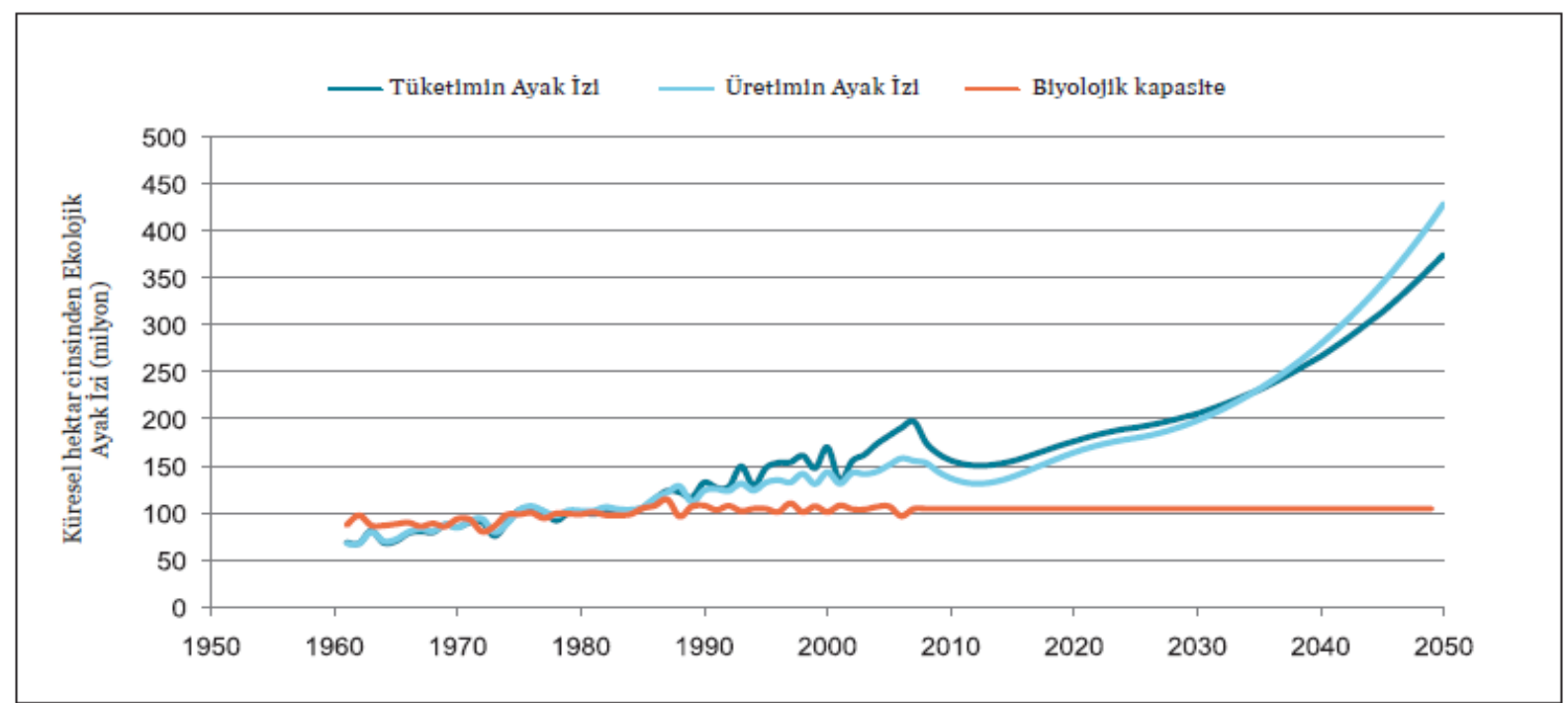

Kaynak: WWF, 2012, s.58

Şekil 3'te küresel ölçekte ekolojik ayak izinin değişimi ve gelecek senaryoları verilmiştir. Şekilde görüldüğü gibi gezegenin insanlığın talebini karşılama kapasitesinin 1970'li yılların sonunda aşılmaya başlandığı, 2007 yılına gelindiğinde ise, ekolojik ayak izinin mevcut biyolojik kapasiteyi \%50 civarında aştığı görülmektedir. Buna göre 2007 yılı itibariyle insanların, faaliyet ve yaşamlarını sürdürebilmek için 1.5 gezegene eşdeğer kaynak kullanmaları gerekmektedir. Mevcut durum, insanların 1 yılda tükettikleri doğal kaynakları yeniden üretmek ve atmosfere salınan karbondioksit $\left(\mathrm{CO}_{2}\right)$ gazının tutulması için 1.5 yıla ihtiyaç olduğunu göstermektedir. Dünyanın biyolojik kapasitesi ile insanlığın ekolojik ayak izi karşılaştıııldığında ekolojik açığın yıllar itibariyle artacağı ön görülmektedir. 2007 yılında 1.5 gezegene ihtiyaç duyulurken 2050 yılına gelindiğinde bu oran 3 gezegene kadar çıkmaktadır (WWF, 2012, s.16).

Şekil 3: Küresel Ekolojik Ayak İzi

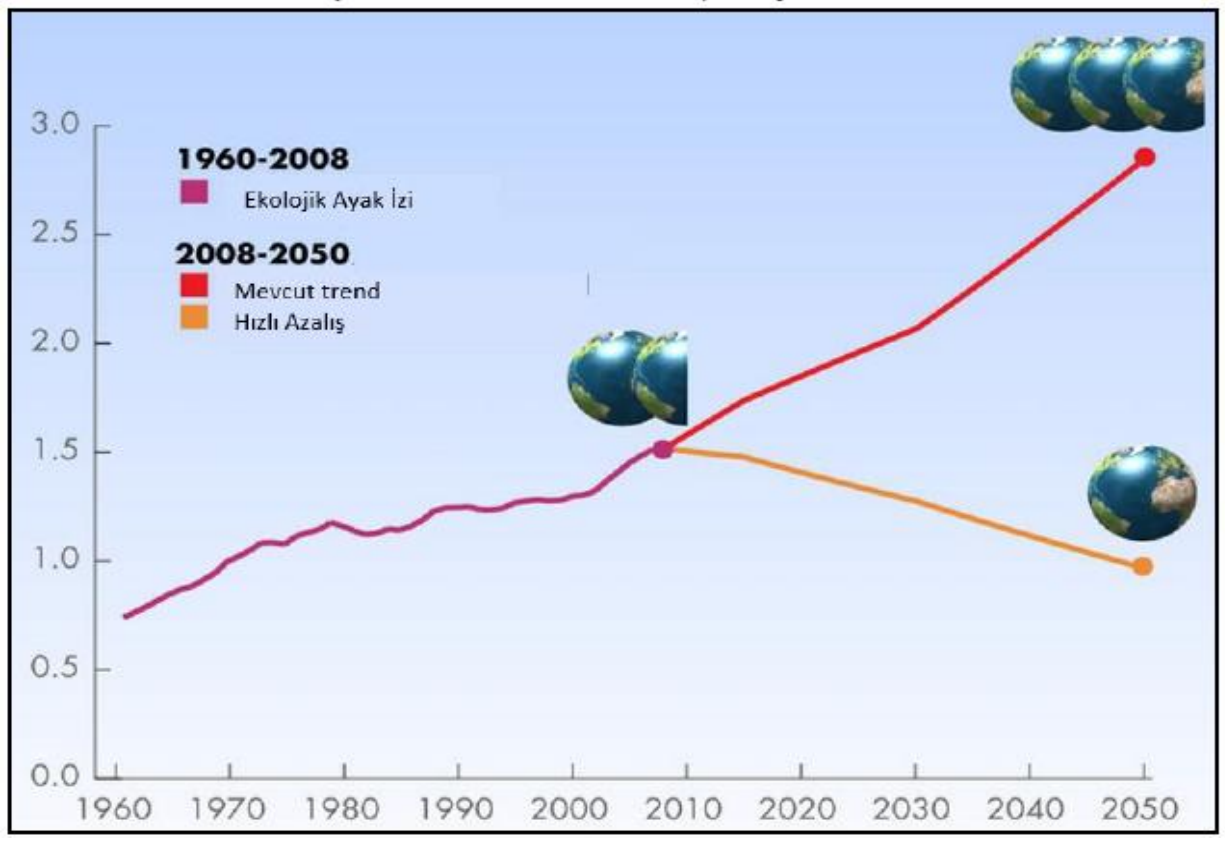

Kaynak: WWF, 2012, s.6.

Şekil 4'te ise 2013 yılında yayınlanan İnsani Gelişme Raporu'nda 2012 yılı verilerine göre dünya genelindeki ülkelerin insani gelişmişlik düzeyleri ve kişi başına düşen ekolojik ayak izleri oranları verilmiştir (UNDP, 2013, s.35). Grafiğin sağ alt köşesindeki bölge, hem yüksek insani gelişmişlik 
seviyesini, hem de düşük ekolojik ayak izini kapsadığı için "Sürdürülebilir İnsani Gelişme” bölgesi olarak adlandırılmıştır.

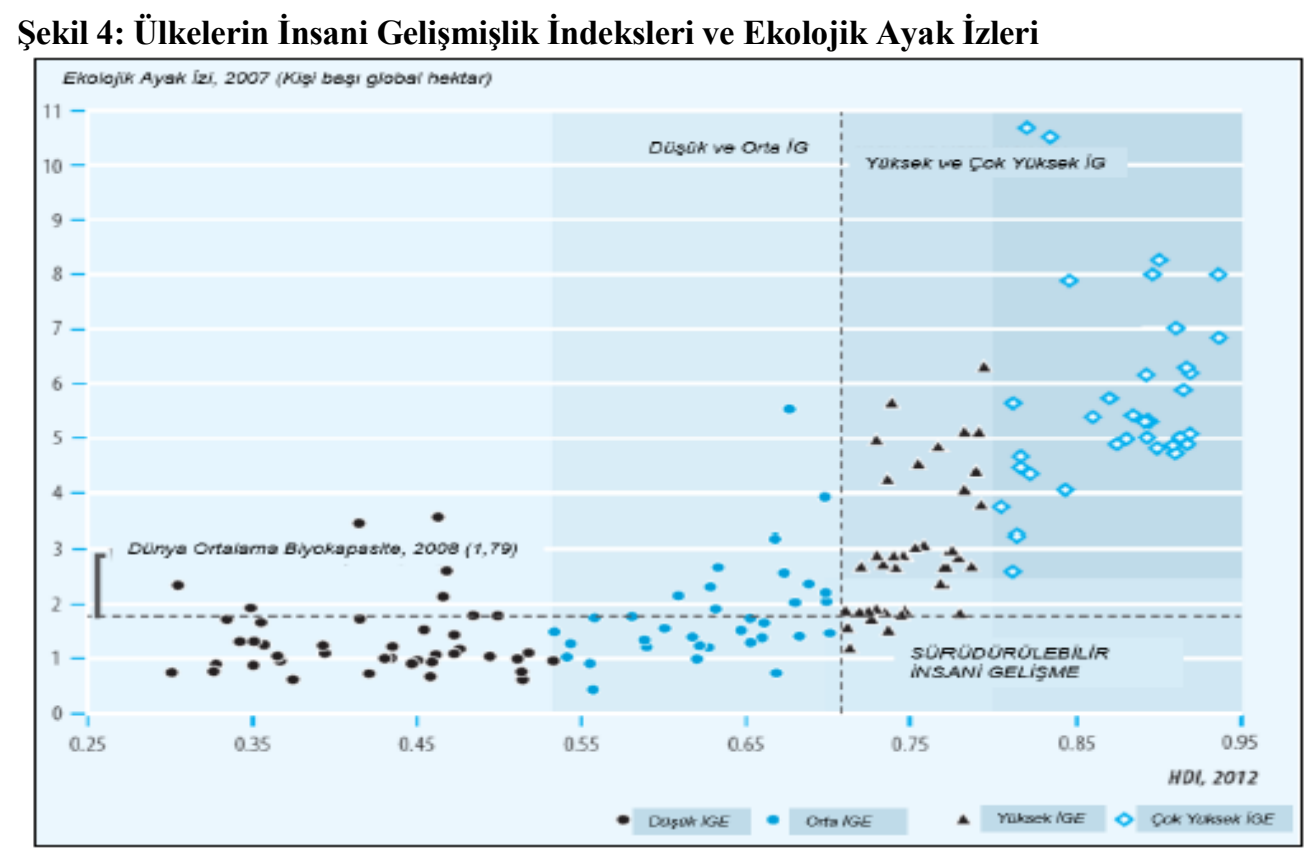

Kaynak: İnsani Gelişmişlik Raporu (UNDP, 2013, s.35).

Şekil 4'teki 151 ülkenin İnsani Gelişme Endeksi (İGE) değerleriyle, ekolojik ayak izi oranları karşılaştırıldığında, yüksek insani gelişme endeksine sahip çok az sayıda ülkenin dünyanın kişi başı 1.79 küresel hektar olan ortalama biyolojik kapasitesinin altında bir ekolojik ayak izine sahip oldukları görülmektedir. Mevcut durum, dünyanın geleceği açısından endişeleri beraberinde getirmektedir. Sürdürülebilir insani gelişme değerine sahip birkaç ülke için dünya ortalama biyokapasitesinin altında bir ayak izine sahip iken, geriye kalan pek çok İGE yüksek olan ülkeler dünya biyokapasite ortalamasının üstünde bir ayak izine sahiptir. Bu tablodan şu anlaşılmaktadır, düşük ve orta İGE'ye sahip olan ülkeler dünya üzerinde daha az ekolojik ayak izine sahip iken yüksek ve çok yüksek İGE'ye sahip olan ülkeler dünya üzerinde daha çok ekolojik ayak izi bırakmaktadır (UNDP, 2013, s.34).

\section{LITERATÜR TARAMASI}

20. yüzyıla kadar toplumlar, refah artışı açısından genelde salt ekonomik gelişme arayışındayken, 20. yy. sonlarında belirgin biçimde ortaya çıkan çevresel sorunlar, sürdürülebilir bir kalkınma için sadece ekonomik gelişmenin değil, aynı zamanda çevreye verdiğimiz tahribatın da dikkate alınmasının gereğini ortaya koymuştur. Bireylerin ve toplumların günlük yaşantılarında çevreye verdikleri tahribatın ölçüsü olarak 1990'lardan itibaren ekolojik ayak izi kavramı standart bir ölçü olarak kullanıldığından son yıllarda sürdürülebilir kalkınmaya yönelik analizler bu kavram üzerinden yapılmaktadır.

Grossman ve Krueger (1991), ekonomik büyüme ve çevre kirliliği arasındaki bağlantıyı incelemiş ve Çevresel Kuznets Eğrisi (ÇKE) hipotezini ortaya atmışlardır. Çevresel Kuznets Eğrisi, ters-U şeklindeki hiperbolik bir ilişkiyi yansıtır. Dolayısıyla, ulaşılan sonuçlar gelir artışıyla birlikte çevre kirliliğindeki önce artan bir ilişkiyi, ardından tepe noktasına ulaştıktan yani belirli bir gelir seviyesinden sonra ülkelerin çevre kirliliğini azalttığını açıklamaktadır. Bununla birlikte ekonomik olarak büyüyen ülkelerin çevre üzerinde daha fazla baskı yaptıkları sonucuna ulaşılmıştır.

Gönel (2002), globalleşen dünyada sürdürülebilir kalkınmada henüz başarıya ulaşılamadığını öne sürerek, sürdürülebilir kalkınmada eko-etkinliğin sağlanabilmesi için üretilen mallarda malzeme yoğunluğunun azaltılmasına, enerji tasarrufu sağlanmasına, zararlı maddelerin çevreye yayılmasının azaltılmasına, yenilenebilir kaynakların artırılmasına ve dayanıklı ürünler üretilmesine dikkat çekmiştir

Çelebioğlu (2011) küresel ekonomik sistemde sürdürülebilir kalkınmayı incelediği çalışmasında kalkınmanın az gelişmiş ülkelerin sorunlarından biri olduğunu, gelişmiş ülkelerde ise dengeli büyüme sonucunda kalkınmanın birlikte geldiğini söylemiştir. Sürdürülebilir bir kalkınma olabilmesi için birçok 
göstergenin gerçekleşmesi gerektiğini belirterek bu göstergelerin; iklim değişimi, temiz su ekosistemleri, kıyı ekosistemleri, kaynak kullanımının etkinliği, yenilenebilir kaynakların yönetimi, karasal ekosistemler, sürdürülebilir tüketim, küresel yoksulluk azalımı, sağlık, refah ve eğitim düzeyi, küresel yoksulluk azalımı, temiz çevre olduğunu ifade etmiştir.

Aslan (2012) çalışmasında temiz üretim teriminin henüz tam karşılığını bulamadığı ve bu yüzden temiz üretim hakkında farkındalık oluşturmak gerektiğini söylemiştir. Çalışmada OECD iklim değişikliği raporuna atıf yapılarak 2050 yılına kadar dünyada sera gazı emisyonlarının $\% 70$ oranında artabileceği belirtilmiştir. Temiz üretim farkındalığı açısından Türkiye'ye bakıldığında ise son 10 yılda temiz üretim alanında gerçekleştirilen çalışmaların sayısında büyük artış meydana gelerek farkındalık oluştuğundan bahsedilmiştir.

Altunok (2013) sürdürülebilir kalkınmanın sürdürülebileceği hakkında yaptığı çalışmasında hızlı nüfus artışı, göç, çarpık kentleşme, artan üretim gibi sebeplerle ekolojik kapasitenin üzerine çıkılacak ekolojik ayak izi baskısının fazlaca artmış olduğuna vurgu yapmış ve sürdürülebilir kalkınmanın sadece bir ütopyadan ibaret olduğunu öne sürmüștür. 26 Şubat 2005 günü Davos Dünya Ekonomik Forumu'nda açıklanan ve 146 ülkeyi içeren çevresel sürdürülebilirlik endeksine göre Türkiye'nin de risk altında olan ülkeler arasında yer aldığı belirtilmiş, sadece ekonomik büyümeyi dikkate alıp doğal kaynakları sınırsızca kullanan ülkelere dikkat çekilmiş ve bu gidişat sonucunda sanayinin denetimden yoksun kalacağı ve kaynakların tükenmesi sorunlarıyla karşılaşılacağı söylenmiştir. Çetinkaya (2013) ise ekokentler ile ilgili çalışmasında ekolojik ayak izinin önemini bahsetmekle birlikte, nüfusun büyük bir bölümünün ticaret ve sanayi ile uğraştı̆̆ ve teknolojik gelişmelerin yaşandığı yerleşim yerlerinde tarımsal faaliyetlerin azalmasına ve buna bağlı olarak enerji tüketiminin artarak çevreye yapmış olduğu tahribata dikkat çekmiştir. Kentlerin bugün itibariyle durumları incelendiğinde doğayı tüketen bir makine haline dönüştüklerini ifade ederek eko-kent kavramıyla kentlerin çevre ile olan etkileşimlerini sağlıklı ve canlı tutmayı amaçlamış, bunun içinde biyolojik çeşitliliğin sağlanması gerektiğini vurgulamıştır. Satır ve Reyhan (2013) ise küresel iklim değişikliğinin dünyada küresel olarak çevresel, sosyal ve ekonomik birçok tehdit oluşturduğunu ifade etmişlerdir. Küresel 1sınmaya karşı bütün ülkelerin ortak hedef politikalar ve protokoller etrafinda birleşmelerinin gerekli olduğunu, ekolojik sistemi bozmadan kalkınmanın yollarını aramaktan başka çare olmadığını belirtmişlerdir. İnsanlarında üretim ve tüketim alışkanlıklarında köklü değişiklikler yapması gerektiği, farkındalık oluşturmak için temiz enerji, eko etiket, yeşil sertifika gibi terimlerin sıklıkla kullanılmasının gerekli olduğuna vurgu yapmışlardır.

Birkan (2014) küresel ısınma ve karbon ayak izini incelediği çalışmasında, küresel ısınmaya neden olan en önemli faktörün atmosferdeki sera etkisine sebep olan gazlardaki artıştan kaynaklandığını belirtmiştir. $\mathrm{Bu}$ sera gazlarının en başında petrol, doğalgaz ve karbondioksit gazı yer almaktadır. Enerji tüketimi sonucunda, her bir tüketimin bir karbon maliyeti bulunmaktadır. Bu yüzden enerji kaynaklarının bilinçsizce tüketilmesi yerine, her bir vatandaşa çevre bilinci aşılayarak yenilebilir temiz enerji kaynaklarına yönelimin gerekliliğinden bahsetmiştir.

Tosunoğlu (2014) sürdürülebilen küresel refah göstergesi olarak ekolojik ayak izini incelediği çalışmasında, 1980 sonrasında sanayileşmenin kentleşmenin, teknolojik ilerlemenin ve nüfustaki hızlı büyümenin ekolojik sorunları beraberinde getirdiğini ifade etmiştir. Ekolojik ayak izi insanın doğadaki baskısını ölçmeye yarayan bir ölçüm aracı olarak tanımlanmıştır. Bu hesaplama yöntemi insanoğlunun kullandığı yeryüzü ve su alanlarını ölçmeye çalışmaktadır. Her ülkenin kaynak kullanım miktarı ve nüfusu farklı yapılarda olduğundan ekolojik ayak izleri de farklılaşmaktadır. Dünyadaki ekolojik ayak izinin azaltılmasına ve sürdürülebilir bir kalkınma gerçekleştirilmesi için kaynakların dikkatli kullanılmasına, biyolojik kapasiteye yatırım yapılmasına, yeşil alanlar artırılmasına ve çevresel sorunlara yönelik çözümler üretilmesinin gerekli olduğuna vurgu yapmıştır.

Keleş (2014) sürdürülebilir ulaşımın ekolojik ayak izi ile ilişkisini incelediği çalışmasında lisans ögrencilerine ekolojik ayak izlerinin azaltılmasına yönelik, ulaşımın öneminden bahsederek bazı sorular yöneltmiştir. Çalışma kapsamında araştırılan ulaşım araçlarının atmosfere saldığı $\mathrm{CO}_{2}$ miktarının, çevreye ve doğal kaynak kullanımına etkisi, trafiğe etkisi, yolcuların sayısı bakımından verimli olup olmadığı gibi birçok boyutunu incelemiş ve ekolojik ayak izinin azalmasına yönelik tüketim alışkanlıklarımızı ve yaşam tarzımızı değiştirmeye yönelik farkındalık oluşturmaya çalışmıştır. 
Reyhan Satır (2014) ise yeşil ekonomi kavramının sürdürülebilir kalkınmada önemini ele almıştır. Çalışmasında sürdürülebilir üretim ve tüketimi sağlamak için doğal kaynakların bilinçli tüketimine, çevreyi korumanın önemine, çevre dostu teknolojilerin geliştirilmesine, toplumsal, siyasal, politika olarak bir dönüşüme vurgu yapmıştır. OECD (2008) tarafından hazırlanan raporda 2050 yılının iklim değişikliği senaryosunda iklim değişikliğinde $2^{\circ} \mathrm{C}$ eşiğini aşmamak için ekonomik büyümenin her yıl $\% 0.2$ azaltılması gerektiği önerilmiştir.

Altınok vd. (2015) küresel iklim değiş̧ikliği sorununun çözümü için yeni bir sürdürülebilir kalkınma anlayışını inceledikleri çalışmalarında küreselleşme ve çevre sorunlarına değinmişlerdir. Çalışmada küresel iklim değişikliğinin dünyadaki etkilerine yer verilmiş ve küresel ısınmanın en önemli nedenini atmosferdeki karbondioksit miktarına bağlamışlardır. Küresel iklim değişikliğinin diğer nedenleri arasında ise metan gazı, gazdaki kurum, karbon monoksit, azot oksit gibi faktörlerin olduğuna vurgu yapmışlardır. Atmosferde yaşanan bu kirliliğe fosil yakıtların kullanımının neden olduğunu ve küresel iklim değişikliği sonucu ortaya çıkacak aşırı sıcaklıkların ekosistemi etkileyeceği hatta 2007 hükümetler arası iklim değişikliği paneli raporunda $1^{\circ} \mathrm{C}$ 'lik bir sıcaklık artışının canlı türlerinin \%30'unu tükenme tehlikesi ile karşı karşıya bırakacağını söylemişlerdir. Sürdürülebilir kalkınmayı ancak çevre dostu teknolojilerin geliştirilmesine bağlamışlar, ayrıca ekolojik ayak izinin önemine de değinerek ekolojik ayak izi, biyolojik ayak izi ve biyolojik kapasite arasındaki farkı belirtmiş̧lerdir. Bu fark büyüdükçe insanların daha fazla tüketim yaptıkları ve kaynaklar üzerinde baskı oluşturduğu vurgulanmıştır.

Artan vd. (2015) ise Türkiye'de çevre kirliliği ile dışa açıklık arasında uzun dönemli ilişki olduğunu tespit etmişlerdir. Çalışmalarının sonucunda Türkiye'de enerji girdisi olarak fosil yakıtları kullanmaktan ziyade yenilebilir enerjiye yönelmenin doğru olacağını söylemişlerdir. Erdem vd. (2015) Avrasya bölgesinde doğal kaynakların kullanımı ve sürdürülebilirlik hakkında yaptıkları çalışmalarında doğal kaynakların büyümede ve kalkınmada önemli yer etmesine rağmen bilinçsiz ve aşırı şekilde kullanıldığında ülkelerin birçok sorunla karşılaşacağını ifade etmişler ve bölgenin ekolojik ayak izleri ve biyokapasiteleri itibariyle sürdürülebilir kalkınmada sürdürülemez bir boyuta geldiğini açıklamışlardır. Araştırmacılar bölgeyi bu olumsuz durumdan kurtarmak ve sürdürülebilir bir ekonomik büyümeyi yeniden çevreye uyarlamak için doğal kaynakların aşırı ve bilinçsiz kullanımından vazgeçilmesi gerektiğini söylemişlerdir.

Bozkurt ve Okumuş (2015) Türkiye'de ekonomik büyüme, enerji tüketimi, serbest ticaret ve nüfus yoğunluğunun $\mathrm{CO}_{2}$ emisyonu üzerindeki etkilerini eşbütünleşme analizi ile incelemişler ve çevresel Kuznetz eğrisi hipotezini Türkiye evreninde test etmeye çalışmışlardır. Çalışmalarında $\mathrm{CO}_{2}$ emisyonu bağımlı değişken ve diğerlerini bağımsız değiş̧ken olarak ele almışlardır. Sonuçlarda $\mathrm{CO}_{2}$ emisyonu ile ekonomik büyüme, enerji tüketimi, dışa açılık ve nüfus yoğunluğu arasında eşbütünleşme olduğunu söylemişlerdir. Sonuç olarak ise bu değişkenlerin birbirini pozitif yönde etkilediğini ve Türkiye bağlamında ÇKE hipotezinin geçerli olduğu sonucuna varmışlardır.

Yeşil ekonomi göstergeleri hakkında çalışma yapan Pezikoğlu (2016) yeşil ekonomi sayesinde sürdürülebilir kalkınmanın devam edebileceğini, doğal kaynakların ve enerji tüketiminin olumsuz etkilerinin de bu yolla azaltılabileceğini söylemiş̧tir. Ayrıca yeşil etiketler hakkında bilgi vererek, yeşil etiketlere örnek olarak karbon ayak izi, organik, çevre dostu gibi tanımlamalar kullanmıştır. Aynı zamanda yeşil ekonomi ve yeşil etiketler konusunda politika yapıcıların daha fazla zaman ayırmalarının önemine vurgu yapmıştır. Gökşen vd. (2016) yeşil bilişim üzerine yaptıkları çalışmalarında dünyadan ve Türkiye'den örnekler ile insanlara yeşil bilişim konusunda farkındalık yaratarak onları daha bilinçli hale getirmeyi amaçlamışlardır. Bu doğrultuda, kamu çalışanlarının yeşil bilgi işlem algısı, enerji tüketimi, enerjiden tasarruf etmeyi öğrenmeleri için incelemelerde bulunmuşlar, enerjinin maliyeti ve bilgisayar kullanıcının yanlış alışkanlıklarına bağlı maliyetleri hesaplamışlardır. Çalışmalarında kullanıcıların cihazları özensiz ve bilinçsiz kullanmalarının sonucunda enerji maliyetinin yaklaşık 7.4 kat daha fazla arttığını gözlemlemişler ve kamu çalışanlarını bu konuda bilinçlendirmek adına önerilerde bulunmuşlardır.

Erden Özsoy ve Dinç (2016) geleneksel enerji üretim ve tüketim alışkanlıklarımızın çevreye, doğal kaynaklara zarar verdiğinden, fosil yakıt kullanımı sonucu oluşan gazların atmosferde sera etkisi yaratarak ekolojik ayak izini artırdığını söylemişlerdir. Ayrıca Türkiye'de ekolojik ayak izinin en önemli nedeninin karbon ayak izi olduğunu belirtmişlerdir. Bu sebeple de Türkiye'nin bu oranı azaltmak için 
doğru politikalar uygulamasına dikkat çekmişlerdir. Özdemir (2017) ise çevre eğitiminin temel vizyonunun ekolojik okuryazarlık olduğuna vurgu yapmıştır. Çevre dostu yaşam tarzına yönelmenin doğru bir adım olacağından ve doğal kaynakları koruyarak kullanmanın sürdürülebilirlik açısından önemine dikkat çekmiştir.

Özgen vd. (2017) Ankara ilindeki 385 tüketicinin ekolojik ayak izleri ve farkındalık düzeyleri hakkında bir araştırma yapmışlardır. Çalışmalarının sonucunda tüketicilerin ekolojik ayak izlerinin düşük olduğu belirtirken ekolojik ayak izinin tüketim alanlarına göre çeşitlilik gösterdiğini bulmuşlardır. Çalışmalarında ekolojik ayak izinin en yüksek olduğu boyut gıda, en az olduğu boyut ise enerji olarak belirtilmiştir. Ayrıca kadınlar ve erkekler arasında da ekolojik ayak izi boyutunda farklılıklar olduğu tespit edilmiştir. Erkeklerin ekolojik ayak izi farkındalığının kadınlardan daha fazla olduğu gözlenmiştir. Özgür (2017) ise nüfus dinamikleri ile çevre ve sürdürülebilirliği inceledikleri çalışmalarında dünyada nüfusun az gelişmiş ülkelerde artmaya devam ettiği ve bu bölgelerde kümeleştiğini ifade etmiștir. Bu nüfus hareketlerinin çevresel bozulmaları, kaynakların tükenmesini, yoksulluğun artmasını tetiklediğini belirtirken küresel boyuttaki bu sorundan en az hasarla kurtulabilmek için sürdürülebilir üretim ve tüketimi güçlendirecek politikalar uygulamasının öneminden bahsetmiştir. Mrabet vd. (2017) finansal gelişme ve ekolojik ayak izi arasındaki ilişkiyi incelemişler, çalışmanın sonucu olarak finansal gelişimin ekolojik ayak izini arttırdığını ortaya çıkarmışlardır.

Dursun vd. (2018) sürdürülebilir kalkınma için çevreci tüketim davranışlarını ölçmeyi amaçlayan çalışmalarında çok boyutlu "çevreci tüketim" ölçeğini geliştirmişlerdir. Bu ölçek doğrultusunda 707 katılımcıdan elde edilen verilerin analizi sonucunda tüketim öncesinde çevreyi koruyan ürünlerin tercihi olan yeşil tüketim ve tüketim sonrasında geri dönüşüm ve kullanım sırasındaki enerji tasarrufunu kapsayan ölçeğin uygun olduğu bulunmuştur. Türkiye'de tüketicilerin çevreye duyarlı davranış sergiledikleri bulgusuna ulaşmışlardır. Aynı yıl Solarin ve Al-mulali, doğrudan yabancı yatırımların $\mathrm{CO}_{2}$ emisyonları, ekolojik ayak izi ve karbon ayak izi üzerinde etkisini belirlemek için panel analizini kullanmışlar ve doğrudan yabancı yatıımın ekolojik ayak izini etkilemediğini tespit etmişlerdir. Ekolojik ayak izi kavramının önemi ve hakkında gittikçe artan farkındalık sonucunda literatürde son yıllarda genişleyen araştırma alanı için ekolojik ayak izine yer veren analizler yapılmaktadır. Örneğin, Aydın vd. (2018) ekolojik ayak izi ile reel gelir arasındaki ilişkiyi panel regresyon modeli ile inceledikleri çalışmaları sonucunda ekolojik ayak izi ile reel gelir arasında pozitif bir ilişki bulmuşlardır. Reel geliri yüksek ülkelerin ekolojik ayak izlerinin de yüksek olduğu sonucuna ulaşmışlardır. Buna göre ülkelerin enerji kullanımının artması sonucunda, ekonomik büyüme olumlu etkilenmekle birlikte, fosil yakıt kullanımının artmasından dolayı ülkelerin ekolojik ayak izlerinde de artış gözlenmiştir.

Ulucak ve Koçak (2018) OECD ülkelerinin ekonomik büyümeleri ve ekonomik büyümenin çevre üzerine etkilerini ekonometrik açıdan inceledikleri çalışmalarında ÇKE'yi panel veri yöntemi ile analiz etmişlerdir. Çalışmalarında çevresel tahribat için ekonomik ayak izi verilerini kullanmışlar ve analizleri sonucunda OECD ülkeleri için ÇKE hipotezi reddedilmiştir. ÇKE hipotezinde ekonomik büyümenin belli bir noktaya kadar kirliliği artırdığı, belirli gelir seviyesine eriştikten sonra ise teknolojik gelişmelerle kirliliğin azaldığını ifade etmektedirler.

Ekolojik ayak izi çevre kirliliğinin yeni bir göstergesi olarak ortaya çıkmasına rağmen $\mathrm{CO}_{2}$ emisyonları daha kapsamlı bir önlem olarak kabul edildiğinden Aydin vd. (2019) ve Solarin (2019) $\mathrm{CO}_{2}$ emisyonlarını çevre kirliliğinin bir göstergesi olarak kullanmışlardır. Ekolojik ayak izi analizini, sürdürülebilir kalkınmanın derecesini nicel olarak ölçen ve yeni gelişmekte olan bir ekolojik ekonomi yöntemi olduğu sonucuna ulaşmışlardır.

\section{VERİ VE METODOLOJI}

Bootstrap Rolling Window tipi nedensellik testi için kurulan vektör otoregresif (VAR) modeli aşağıda yer alan denklem (1) ve (2)'de gösterilmektedir:

$$
\begin{aligned}
& E F_{t}=\sum_{i=1}^{k+d_{\max }} \sigma_{1 i} E F_{t i}+\sum_{i=1}^{k+d_{\max }} \mu_{1 i} B C_{t i}+\varepsilon_{1 t} \\
& B C_{t}=\sum_{i=1}^{k+d_{\max }} \sigma_{1 i} B C_{t i}+\sum_{i=1}^{k+d_{\max }} \mu_{1 i} E F_{t i}+\varepsilon_{2 t}
\end{aligned}
$$


Eşitlik 1 ve 2'de yer alan EF ekolojik ayak izini ve BC biyokapasite göstergesini ifade etmektedir. Modelde yer alan dmax değişkenlerin maksimum eşbütünleşme derecelerini, $\varepsilon$ hata düzeltme terimini ve k simgesi de optimal gecikme uzunluğunu göstermektedir. Veriler 1961-2016 dönemi için yıllık olarak Global Ayak İzi Ağı veri tabanından derlenmiştir. Bu iki değişken arasındaki uzun dönemli ilişkiyi tespit etmek amacıyla Balcılar vd. (2010) tarafından geliştirilen Bootstrap Rolling Window Nedensellik Testi uygulanmışır.

\section{AMPİRIK BULGULAR}

Türkiye için ekolojik ayak izi ve biyokapasite değişkenlerine ait tanımlayıcı istatistiklere Tablo 1'de yer verilmektedir.

Tablo 1: EF ve BC Değişsenlerine Ait Tanımlayıcı İstatistikler

\begin{tabular}{|c|c|c|c|c|c|c|c|}
\hline Değişkenler & Gözlem & Ortalama & Maksimum & Minimum & $\begin{array}{c}\text { Standart } \\
\text { Sapma }\end{array}$ & Çarpıklık & Basıklık \\
\hline EF & 56 & 2.443 & 3.39 & 1.60 & 0.54 & 0.225 & 2.131 \\
\hline BC & 56 & 2.013 & 2.81 & 1.44 & 0.37 & 0.255 & 1.885 \\
\hline
\end{tabular}

Tanımlayıcı istatistiklerden oynaklığın bir göstergesi olan standart hataya bakıldığında EF değişkeninin $\mathrm{BC}$ değișkenine göre oynak olduğu görülmektedir. Çarpıklık değerleri incelendiğinde her iki değişkenin de sağa çarpık olduğu anlaşılmaktadır. Basıklık katsayısı incelendiğinde ise değişkenlerin basık olduğu tespit edilmektedir.

VAR [p veya (populasyon)] modelinde yer alan değişkenler arasındaki ilişkilerin anlamlı ve güvenilir çıkabilmesi için serilerin birim köke sahip olmaması başka bir ifadeyle durağan olması gerekmektedir. Serilerin durağanlık durumunu tespit etmek amacıyla gerçekleştirilen birim kök testi bulguları Tablo 2 'de yer almaktadır.

Tablo 2: ADF (1981) ve PP (1988) Birim Kök Testi Bulguları

\begin{tabular}{|c|c|c|c|c|c|c|c|c|}
\hline \multirow{5}{*}{ 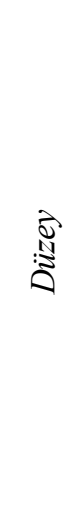 } & & Değişkenler & $\mathrm{ADF}$ & PP & \multirow{5}{*}{ 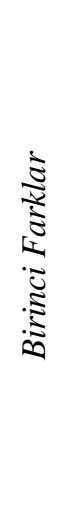 } & Değişkenler & ADF & PP \\
\hline & \multirow{2}{*}{ Sabit } & EF & $\begin{array}{c}-0.6005 \\
(0.861)\end{array}$ & $\begin{array}{l}-0.670 \\
(0.845)\end{array}$ & & $\mathbf{E F}$ & $\begin{array}{l}-12.024 \\
(0.000)\end{array}$ & $\begin{array}{r}-18.916 \\
(0.000)\end{array}$ \\
\hline & & BC & $\begin{array}{l}-1.695 \\
(0.427)\end{array}$ & $\begin{array}{l}-1.226 \\
(0.656)\end{array}$ & & BC & $\begin{array}{l}-7.182 \\
(0.000)\end{array}$ & $\begin{array}{r}-19.611 \\
(0.000)\end{array}$ \\
\hline & \multirow{2}{*}{ Sabit+Trend } & $\mathbf{E F}$ & $\begin{array}{l}-5.798 \\
(0.000)\end{array}$ & $\begin{array}{l}-5.877 \\
(0.000)\end{array}$ & & $\mathbf{E F}$ & $\begin{array}{l}-11.911 \\
(0.000)\end{array}$ & $\begin{array}{c}-19.993 \\
(0.000)\end{array}$ \\
\hline & & BC & $\begin{array}{l}-5.237 \\
(0.000)\end{array}$ & $\begin{array}{l}-5.133 \\
(0.000)\end{array}$ & & BC & $\begin{array}{l}-7.341 \\
(0.000)\end{array}$ & $\begin{array}{r}-23.079 \\
(0.000)\end{array}$ \\
\hline
\end{tabular}

Dickey Fuller (1981) tarafından geliştirilen ADF ve Phillips Perron (1988) tarafindan geliştirilen PP birim kök testleri sonuçlarında sabit terimin yer aldığı modelde $\mathrm{EF}$ ve $\mathrm{BC}$ değişkenlerinin birinci derece farkı alındığında serilerin \%1 anlam düzeyinde durağanlaştığı ya da istatistiksel olarak anlamlı çıktığı görülmektedir. Sabitli ve trendli modelde ise gerek düzey seviyede gerekse birinci derece fark1 alındığında serilerin durağan oldukları birim kök testleri sonucunda ortaya çıkmaktadır. Değişkenler arasında uzun dönemli bir ilişkinin olup olmadığını ortaya koyabilmek için yapılan eşbütünleşme testi bulgularına Tablo 3'te yer verilmektedir. 
Tablo 3: Johansen Eşbütünleşme Testi Bulguları

\begin{tabular}{|c|c|c|c|c|}
\hline \multicolumn{5}{|c|}{ İz (Trace) Testi } \\
\hline $\begin{array}{c}\text { Eşbüitünleşme } \\
\text { Sayısı }\end{array}$ & Özdeğer & İz İstatistiği & $\mathbf{0 . 0 5}$ Kritik Değer & Olasılık (p) Değeri \\
\hline $\mathrm{r}=0$ & 0.269663 & 17.6634 & 15.4947 & 0.0232 \\
\hline $\mathrm{r} \leq 1$ & 0.012769 & 0.6939 & 3.84146 & 0.4048 \\
\hline
\end{tabular}

\begin{tabular}{|c|c|c|c|c|}
\hline \multicolumn{5}{|c|}{ Maksimum Özdeğer Testi } \\
\hline $\begin{array}{c}\text { Eşbütünleşme } \\
\text { Sayısı }\end{array}$ & Özdeğer & $\begin{array}{c}\text { Maksimum } \\
\text { Özdeğer } \\
\text { İstatistiği }\end{array}$ & $\mathbf{0 . 0 5}$ Kritik Değer & Olasilık (p) Değeri \\
\hline $\mathrm{r}=0$ & 0.269663 & 16.9694 & 14.2646 & 0.0182 \\
\hline $\mathrm{r} \leq 1$ & 0.012769 & 0.6939 & 3.84146 & 0.4048 \\
\hline
\end{tabular}

Tablo 3'teki bulgular incelendiğinde ilgili değişkenler için eşbütünleşme yoktur sıfir hipotezinin reddedilerek aralarında en az bir tane eşbütünleşik vektöre sahip olduğu iz testi ve maksimum özdeğer testi olasılık değerlerinden anlaşılmaktadır. Böylelikle ekolojik ayak izi ve biyokapasite arasında uzun dönemli bir ilişkinin varlığ tespit edilmiştir. Türkiye için ekolojik ayak izi ve biyokapasite arasındaki iliş̧iyi bootstrap rolling window yaklaşımı ile inceleyen nedensellik testi sonucuna aşağıda yer alan Tablo 4'de yer verilmektedir.

Tablo 4: Türkiye İçin Bootstrap Rolling Window Nedensellik Testi Bulguları

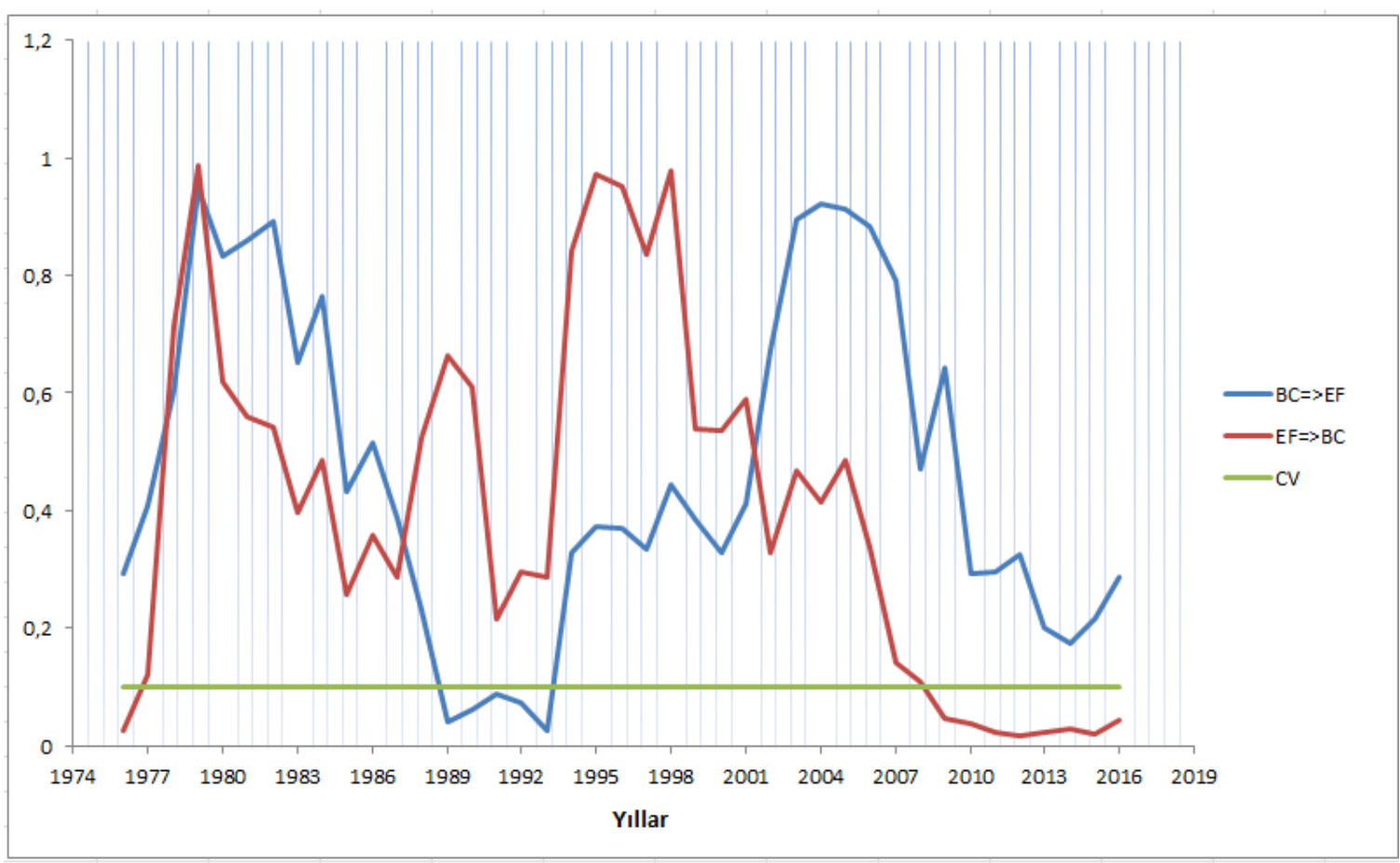

Tablo 4'e bakıldığında Türkiye'de 1976 ve 1977 yıllarında ekolojik ayak izinden biyolojik kapasiteye doğru tek taraflı bir bootstrap rolling window nedensellik olduğu görülmektedir. Türkiye çevresel problemlerle ve bu problemlerin insan sağl 1 ğ ve yaşamına olumsuz etkileriyle 70'li yıllarda tanışmıştır. Türkiye çevresel çözüm politikalarını diğer ülkelere göre daha geç benimsemiştir. Dünya'da o yıllarda çevre ile ilgili pek çok sözleşmeler yapılmış, örneğin 1972'de BM İnsan ve Çevre Konferansı Bildirgesi ve aynı yıl Paris’te Dünya Kültürel ve Doğal Mirasın Korunması Sözleşmesi imzalanmıştır. Bununla birlikte Türkiye'de 1988 ve 1993 yılları arasında biyolojik kapasiteden ekolojik kapasiteye doğru tek 
taraflı bir nedensellik olduğu görülmektedir. Türkiye bu yıllarda çevresel ve iklim sorunlarının kısmen farkına varmış ve çevreyi korumaya yönelik hukuki düzenlemeler almıştır. 1992 yılında RİO Dünya Zirvesi’nde biyolojik çeşitlilik ve iklim değişikliği sözleşmesi yapılmıştır. Türkiye bu sözleşmeye 1996 yılında taraf olmuştur. Türkiye'de asıl çevreye yönelik hukuki düzenlemelerin 2000'li yıllardan sonra yapıldığı göz önünde bulundurulsa da 2008 ve 2016 yılları arasında ekolojik ayak izinden biyolojik kapasiteye doğru tek taraflı bir nedensellik olduğu görülmektedir. Türkiye'de 2005 yılında yürürlüğe giren Kyoto Protokolüne uyarak küresel ısınma ve iklim değişikliği ile ilgili birtakım önlemler alarak, daha sonra 2008 küresel finans krizinin etkilerinin tüm dünyada görülmesiyle birlikte Türkiye bazı finansal önlemler de almıştır. Haziran 2012'de gerçekleştirilmiş olan Birleşmiş Milletler Sürdürülebilir Kalkınma Konferansında (Rio+20) çevresel sürdürülebilirlik kavramlarının kalkınma modellerine dâhil edilmesi gerektiğinin tekrar vurgulanması konunun önemini bir kez daha ortaya çıkarmıştır.

\section{SONUÇ}

Çevresel sürdürülebilirliği ölçülebilir kılmayı sağlayan ekolojik ayak izi kavramı, doğa ve insan arasındaki ilişkiyi yeni bir bakış açısıyla ele almakta ve doğal kaynakların üzerindeki baskının niceliğini ve bunun hangi etmenlerden kaynaklandığını ortaya koymaktadır. Bu çalışmada ekolojik ayak izleri ve biyokapasite arasında nedensellik ilişkisinin olduğu hipotezi test edilmeye çalışılmıştır. Analizde uygulanan Bootstrap Rolling Window nedensellik testi sonucuna göre Türkiye öznelinde ekolojik ayak izleri ve biyokapasite arasında; 1988-1993 yılları arasında biyokapasiteden ekolojik ayak izlerine, 19761977 ve son 2008-2016 yılları arasında ekolojik ayak izlerinden biyokapasiteye doğru tek taraflı bir Granger nedensellik ilişkisi tespit edilmiştir. Türkiye için son dönemde elde edilen bu bulgular literatürde gerçekleştirilen Aydın vd. (2019), Solarin (2019) ve Bozkurt ve Okumuş (2015) gibi çalışmalarla da desteklenmektedir.

Türkiye'de doğal kaynakların tüketilme hızının üretilme hızından daha fazla olması ekolojik açığı giderek büyütmektedir. WWF 2012 raporuna göre Türkiye'de kişi başına tüketimin ekolojik ayak izi dünya ortalamasına eşitken, kişi başına biyolojik kapasitesi dünya ortalamasının altındadır. Bu durum Türkiye'de yaşayan insanların dünya ortalamasından daha yüksek bir ekolojik borcunun olduğunu göstermektedir. 1989 yılından itibaren Türkiye'nin yurt dışından ithal ettiği doğal kaynak miktarının ihraç ettiğinden daha fazla olması sonucunda ekolojik ticaret açığı artmakta ve bu durum biyolojik kapasite ithalatçısı olmasına neden olmaktadır. Son 20 yıllık süre içerisinde ülke tüketimimiz, giderek doğrudan hammadde ve dolaylı yoldan ithal edilen ürünlerdeki girdiler olarak yabancı kaynaklara dayanmaktadır. Mevcut durum bu şekilde devam ederse, gelecek yıllarda sürekli büyüyen ekolojik ayak izine karşın giderek azalan bir biyolojik kapasite sorunuyla karşı karşıya kalınması kaçınılmaz olacaktır.

Bugün gelinen noktada, yaşam tarzımızın ve dünyanın ekolojik kapasitesinin ekolojik ayak izi perspektifinden tekrar gözden geçirilmesi bir zorunluluktur. Türkiye de ekolojik ayak izi bilançosunu çıkaran ülkelerden biri olarak, sürdürülebilir kalkınma konusunda başarı sağlamak istiyorsa ekolojik açığını kapatmaya yönelik adımlar atmalıdır. Bunlar arasında, ilk olarak ülke dışından karşılanan ithal kaynaklara olan bağımlığı azaltarak biyolojik kapasiteyi korumaya ve artırmaya yönelik yatırımlar artırılmalıdır. Ekonomik faaliyetlerin devamlılı̆̆ını sağlayan, sürdürülebilir çevre politikalarıyla biyolojik çeşitliliğin korunması sağlanmalıdır. İklim değişikliği, işsizlik, yoksulluk ve kaynakların verimsiz kullanımı sorunlarına çözümler üretilmelidir. Türkiye'de artan nüfus artışı ve büyüme doğal kaynaklara olan talebi artırmakta, bu durum da artan ihtiyacı karşılamak üzere üretim alanlarına dönüştürülmektedir. Bu yüzden mevcut alanların verimliliği artırılarak, doğal alanlar işgal edilmemelidir. Kentlerin planlanmasının biyolojik kapasite üzerindeki etkisi önemlidir. Yeni yapılan yapılaşmaların olabildiğince biyolojik olarak verimli arazilerden ziyade düşük verimlilikteki bölgelere açılması gerekmektedir. Binalar doğal kaynakları verimli kullanan teknolojilerle inşa edilmeli, yeşil alanlar korunmalı ve artırılmalıdır. Fosil kaynaklı enerji tüketiminden ziyade yenilenebilir enerji kullanımına önem verilmelidir. Tarımsal üretimde iyi tarım ve organik tarım gibi uygulamalar tercih ve teşvik edilmelidir. İsrafa yönelik tüketime son verilerek karar verici yönetici mercilerin çevresel politikalarda farkındalığı artırma çabaları toplumun geniş kesimlerine yayılmalı ve toplum bilinçlendirilmelidir. Kamu kurumları, özel sektör, sivil toplum kuruluşları, üniversiteler ve diğer ilgi grupları çevresel sorunları ele almak için ortak hareket etmelidir. 


\section{KAYNAKÇA}

Alam, M. M., Murad, M. W., Noman, A. H. M., \& Ozturk, I. (2016). Relationships among carbon emissions, economic growth, energy consumption and population growth: Testing Environmental Kuznets Curve hypothesis for Brazil, China, India and Indonesia. Ecological Indicators, 70, 466-479.

Altınok, S., Fırat, E. ve Soyu, E. (2015). Küresel iklim değişikliği sorununun çözümü için yeni bir sürdürülebilir kalkınma anlayışı. International Conference on Eurasian Economies, 620-627.

Altunok, A. E. (2013). Sürdürülebilir kalkınmanın sürdürülemezliği. Denetişim, 12, 39-44.

Artan, S., Hayaloğlu, P. ve Seyhan, B. (2015). Türkiye'de çevre kirliliği, dışa açıklık ve ekonomik büyüme ilişkisi. Yönetim ve Ekonomi Araştırmaları Dergisi, 13(1), 308-325.

Aslan E. (2012). Temiz üretim (Eko-verimlilik). Kalkınmada Anahtar Verimlilik Dergisi, 280, 4-5.

Aydın, C., Darıcı, B. ve Şahin Kutlu, Ş. (2018). Ekolojik ayak izi ile reel gelir arasındaki ilişki: Panel yumuşak geçişli regresyon modelinde kanitlar. International Conference on Empirical Economics and Social Sciences (ICEESS'18), Bandırma, Türkiye.

Aydin, C., Esen, Ö., \& Aydin, R. (2019). Is the ecological footprint related to the Kuznets curve a real process or rationalizing the ecological consequences of the affluence? Evidence from PSTR approach. Ecological Indicators, 98, 543-555.

Balcilar, M., Ozdemir, Z. A., \& Arslanturk, Y. (2010). Economic growth and energy consumption causal nexus viewed through a bootstrap rolling window. Energy Economics, 32(6), 1398-1410.

Başoğlu, A. ve Akyazı, H. (2015). Çevresel sorunların makroekonomik analizinde çevreye uyarlanmış IS-LM modeli. Marmara Üniversitesi İ.I.B. Dergisi, 37(2), 129-152.

Birkan, İ. (2014). Küresel ısınma ve karbon ayak izimiz. 3 Temmuz 2019 tarihinde http://www.turkishnews.com/tr/content/wp-content/uploads/2014/08/kuresel-1sinma-ve-karbonayak-1zımız.pdf adresinden erişildi.

Bozkurt, C. ve Okumuş, İ. (2015). Türkiye'de ekonomik büyüme, enerji tüketimi, ticari serbestleşme ve nüfus yoğunluğunun $\mathrm{CO}_{2}$ emisyonu üzerindeki etkileri: Yapısal Kırılmalı Eş Bütünleşme Analizi. Mustafa Kemal Üniversitesi Sosyal Bilimler Enstitüsü Dergisi, 12(32), 23-35.

Çelebioğlu, F. (2011). Küresel ekonomik sistemde sürdürülebilir kalkınma. (Eds. Altay, H ve Şen, A. Küresel Ekonomi Sorunlar ve Çözüm Önerileri, 77-100). Ankara: Detay Yayıncılık.

Çetinkaya, Ç. (2013). Eko-kentler: kent ve doğa ilişkisinde yeni bir sistem tasarımı. Türk Bilimsel Derlemeler Dergisi, 6(1), 12-16.

Dickey, D.A. \& W.A. Fuller (1981), Distribution of the estimators for autoregressive time series with a unit root. Econometrica, 49, 1057-72.

Dursun, İ., Tümer Kabadayı, E. ve Tuğer, A. T. (2018). Çevreci tüketim davranışı: boyutları ve ölçümü. Ömer Halisdemir Üniversitesi İktisadi ve İdari Bilimler Fakültesi Dergisi, 11(3), 42-66.

Erdem, E., Ulucak, R. ve Yücel, A. G. (2015). Avrasya bölgesinde doğal kaynak kullanımı ve sürdürülebilirlik. Dünya Enerji Kongresi 2015.Torino, İtalya.

Erden Özsoy C. ve Dinç, A. (2016). Sürdürülebilir kalkınma ve ekolojik ayak izi. Finans Politik \& Ekonomik Yorumlar, 53(619), 35-55.

Gökşen Y., Damar, M. ve Doğan, O. (2016). Yeşil bilişim: bir kamu kurumu örneği ve politika Önerileri. Ege Akademik Baklş, 16(4), 673-686.

Gönel, F. D. (2002). Globalleşen dünyada (nasıl bir) sürdürülebilir kalkınma. Birikim Dergisi, 158, 7280.

Grossman, G. M., \& Krueger, A. B. (1991). Environmental impacts of a North American free trade agreement (No. w3914). National Bureau of Economic Research. 
Keleş, Ö. (2014). Sürdürülebilir ulaşımı tercih edin ekolojik ayak iziniz azalsın. Araştırma Temelli Etkinlik Dergisi (ATED), 1, 46-57.

Mrabet, Z., AlSamara, M., \& Hezam Jarallah, S. (2017). The impact of economic development on environmental degradation in Qatar. Environmental and Ecological Statistics, 24, 7-38.

OECD (Organization for Economic Cooperation and Development) (2008). Annual Report 2008. Paris: OECD Publishing.

Özdemir, O. (2017). Ekolojik okuryazarlık ve çevre eğitimi (2. Baskı). Ankara: Pegem Akademi Yayıncilik.

Özgen, U., Demirci A., Aksoy, A. (2017). Tüketicilerin ekolojik ayak izi farkındalık düzeyleri (Ankara İli Örneği). Üçüncü Sektör Sosyal Ekonomi, 52(3), 46-65.

Özgür, E. M. (2017). Nüfus dinamikleri, çevre ve sürdürülebilirlik. Coğrafi Bilimler Dergisi, 15(1), 126.

Pezikoğlu, F. (2016).Yeşil ekonomi göstergeleri ve yeşil ekonomi. XII. Ulusal Tarım Ekonomisi Kongresi, Süleyman Demirel Üniversitesi, Isparta.

Phillips, P.C.B. \& P. Perron. (1988), Testing for a unit root in time series regression, Biometrika 75, 335-346.

Reyhan Satır, A. (2014). Sürdürülebilir üretim-tüketim politikaları çerçevesinde "yeşil ekonomi" üzerine bir değerlendirme. Memleket Siyaset Yönetim Dergisi (MSY), 9(22), 327-347.

Satır, A. ve Reyhan, H. (2013). Küresel iklim değişikliği sorununa çözüm için nasıl bir sürdürülebilir kalkınma anlayışına ihtiyacımız var? International Conference on Eurasian Economies 2013, 962-964.

Solarin, S. A. (2019). Convergence in $\mathrm{CO}_{2}$ emissions, carbon footprint and ecological footprint: Evidence from OECD countries. Environmental Science and Pollution Research, 6167-6181.

Solarin, S. A., \& Al-Mulali, U. (2018). Influence of foreign direct investment on indicators of environmental degradation. Environmental Science and Pollution Research, 25(25), 2484524859.

Tosunoğlu, B. T. (2014). Sürdürülebilir refah göstergesi olarak ekolojik ayak izi. HAK-IŞ̧ Uluslararası Emek ve Toplum Dergisi, 3(5), 132-149.

Ulucak, R. \& Bilgili, F. (2018). A reinvestigation of EKC model by ecological footprint measurement for high, middle and low income countries. Journal of Cleaner Production, 188, 144-157.

Ulucak, R. ve Koçak, E. (2018). Economic growth and environment: Econometric analysis for OECD countries. Dünya Enerji Kongresi 2018. Amsterdam, Hollanda.

UNDP (United Nations Development Programme). (2013). Human Development Report 2013: The Rise of the South. New York, ABD: UNDP.

WWF (2012). Türkiye'nin ekolojik ayak izi raporu 2012. Türkiye: Türkiye Dünya Doğayı Koruma Vakfi. 